\title{
CONFESSIONALITY IN STRATEGIC MANAGEMENT OF CONFESSIONAL EDUCATION INSTITUTION
}

\author{
Flavio Roberto Mantovani and Adilson Aderito da Silva \\ Universidade Presbiteriana Mackenzie, Rua da Consolação, 930, São Paulo, SP, Brazil
}

\begin{abstract}
The present research has the purpose of characterizing the mechanisms of spreading confessionality in Confessional Higher Education Institutions (CHEIs), in order to answer the following research question: How may the confessional dimension, with the use of the Balanced Scorecard, be addressed in the strategic management of a Confessional Higher Education Institution? Using the factor analysis technique, two main components, interpreted as "practiced" confessionality and "latent" confessionality, have been identified. From these findings, employing the techniques of the Balanced Scorecard management model, strategic objectives which aim at the communication and implementation of confessionality are suggested, enabling the CHEIs to properly manage confessionality in the various dimensions of the proposed model.
\end{abstract}

KEYWORDS

Confessionality, Higher Education Institution, Strategic Management

\section{INTRODUCTION}

Considering the legitimate expression of moral values and worldview, confessionality underpins the objectives, defined by the maintainer, as for the existence and functioning of the maintained organization, thus constituting a strategic dimension in management process. Thus, this research has the core purpose of characterizing the mechanisms of confessionality dissemination in a Confessional Higher Education Institution, in order to answer the following research question: How may the confessional dimension, through the use of the Balanced Scorecard, be addressed in the strategic management of a Confessional Higher Education Institution?

\section{LITERATURE REVIEW}

Regarding the theme of confessionality, the main references were: BORGES (2008); LOPES, (2005); VASSELAY (2001). Regarding to the BSC: KAPLAN (1997).

\section{METHODOLOGY}

Data collection and analysis occur in two phases. In the first, data collection is conducted to identify and characterize the confessionality practiced. The second phase takes place through a questionnaire composed of assertions evincing confessionality, elaborated on an eight-point scale, from the categories identified in the first phase.

\section{FINAL CONSIDERATIONS}

The exploratory survey conducted with the students indicates two main components referring the perception of the confessionality disclosure. Statistically, they are termed as "Practiced Confessionality" and "Latent Confessionality". Based on these findings it was possible to determine the strategic objectives.

\section{REFERENCES}

Borges, I. A. (2008). Confessionalidade e construção ética na universidade. São Paulo: Ed. Mackenzie, 2008. Kaplan, R. S.; Norton, D. P. (1997). A estratégia em ação: balanced scorecard. 14. ed. Rio de Janeiro: Campus. Lopes, V. G. (2005). Fundamentos Epistemológicos do Ensino Religioso Confessional e Plural. Rio de Janeiro, texto apresentado no $1^{\circ}$ Seminário de Ensino Religioso do Leste I, promovido pelo Regional Leste e pela SEE/RJ, UERJ.

Vasselai, C. (2001). Universidades confessionais no ensino superior brasileiro: identidade, contradições e desafios. Dissertação de Mestrado. Universidade Estadual de Campinas, Faculdade de Educação. Campinas, SP. 